\title{
JATROPHA SEED OIL CONTENT AND YIELD UNDER DIFFERENT IRRIGATION AND POTASSIUM FERTILIZATION LEVELS
}

\section{FÁBIO P. DE DEUS ${ }^{1}$, MANOEL A. DE FARIA ${ }^{2}$, EDNALDO L. DE OLIVEIRA ${ }^{3}$, PEDRO CASTRO NETO ${ }^{4}$}

\begin{abstract}
The aim of this research was to evaluate the effects of different irrigation depths and potassium dosages, of Jatropha seed oil content and yield. The experimental design used was randomized blocks, in split-plots, with four replicates. The treatments were four water depths (plots) and four potassium dosages (subplots) applied through irrigation water. The water depths were applied based on the percentage of accumulated evaporation of a Class A (ECA) tank and of rainfall, as following: $\mathrm{LO}=$ without irrigation, L40, L80 and L120, representing 40, 80 and $120 \%$ of the balance, respectively. The potassium dosages were K30, K60, K90 and K120 (30, 60, 90 and $120 \mathrm{~kg} \mathrm{ha}^{-1}$ of potassium, respectively). The oil extraction of samples was done through chemical extraction by organic solvent. The seeds used in this test were from the sampling of two seed productions from 2009, second year of crop production. It was possible to observe that irrigation use increased oil yield and decreased the oil content of Jatropha seed. Potassium fertilization did not influence oil content and yield. There was a relative increase of efficiency in water use producing oil until certain water depth, and after that there was a decrease.
\end{abstract}

KEYWORDS: chemical extraction, biodiesel, oilseed, drip irrigation.

\section{TEOR E PRODUÇÃO DE ÓLEO DE PINHÃO-MANSO SUBMETIDO A DIFERENTES NÍVEIS DE IRRIGAÇÃO E ADUBAÇÃO POTÁSSICA}

RESUMO: Este trabalho teve como objetivo avaliar os efeitos de diferentes lâminas de irrigação e doses de potássio no teor e produção de óleo de pinhão-manso. Foi utilizado o delineamento experimental em blocos casualizados, em parcelas subdivididas, com 4 repetições. Os tratamentos constaram de 4 lâminas de água e 4 doses de potássio aplicadas via água de irrigação. Aplicaram-se as lâminas de água com base na porcentagem do saldo da evaporação acumulada do tanque Classe A (ECA) e das precipitações, sendo as seguintes: L0 = sem irrigação; L40, L80 e L120, representando 40; 80 e 120\% do saldo, respectivamente. As doses de potássio foram de: K30; K60; K90 e K120, sendo 30; 60; 90 e $120 \mathrm{~kg} \mathrm{ha}^{-1}$ de potássio, respectivamente. A extração do óleo das amostras foi realizada por meio da extração química por solvente orgânico. As sementes utilizadas neste teste foram provenientes de amostragem das duas produções de sementes referentes ao ano de 2009, segundo ano de produção da cultura. Concluiu-se que a utilização da irrigação proporcionou aumento da produtividade de óleo e decréscimo do teor de óleo dos grãos de pinhão-manso. A adubação potássica não influenciou o teor e a produtividade de óleo. Houve aumento relativo da eficiência no uso da água em produzir óleo até determinada lâmina de água e posterior decréscimo.

PALAVRAS-CHAVE: extração química, biodiesel, oleaginosa, gotejamento.

\section{INTRODUCTION}

Currently, petroleum, coal and natural gas are the main sources of raw material for the production of energy in the world. However, the expected depletion of its reserves, combined with price swings and concern over global climate changes are some concerns that increase motivation

\footnotetext{
${ }^{1}$ Doutorando em Engenharia Agrícola, Faculdade de Engenharia Agrícola, UNICAMP.

${ }^{2}$ Professor Titular, Departamento de Engenharia, UFLA.

${ }^{3}$ Professor no Instituto Federal do Norte de Minas Gerais, IFNMG.

${ }^{4}$ Professor Titular, Departamento de Engenharia, UFLA.

Recebido pelo Conselho Editorial em: 18-1-2011

Aprovado pelo Conselho Editorial em: 17-6-2012
} 
and demand for biodiesel in Brazil and worldwide (TRZECIAK et al. 2008). Specifically in Brazil, increased demand for biodiesel is also due to incentives provided by its legislation, where, through the passage of the law number 11,097, on January 13, 2005, it has established a plan to increase the biodiesel blend with petroleum diesel, which, since January 2010, the National Energy Policy Council (CNPE) put in place a 5\% blend of biodiesel with petroleum diesel (TRZECIAK et al., 2008).

Overall, the content and quality of oil, the production per unit area, the adaptation to different production systems, crop cycle and regional adaptation, are essential factors to be considered for biodiesel production. Brazil has a great diversity of oleaginous plant species from which it is possible to produce biodiesel, especially Jatropha seed, which is a bushy plant belonging to the family Euphorbiaceae, Jatropha genus, species Jatropha curcas L.. According to some authors, Jatropha is considered a primitive culture which adapts to different edaphoclimatic conditions, with high productivity and quality of oil, which in terms of commercial cultivation, aimed at high productivity, requires water and soils with good fertility (ARRUDA et al, 2004; LAVIOLA \& DIAS, 2008; OLIVEIRA et al., 2009).

TEIXEIRA (2005) states that, in commercial terms, the average productivity of Jatropha is $5,000 \mathrm{~kg} \mathrm{ha}^{-1}$ for the established culture and on favorable conditions, with around $32 \%$ of this value is converted to vegetable oil, i.e., about $1,600 \mathrm{~kg} \mathrm{ha}^{-1}$. According to data from EPAMIG (2006), the production of oil from the seeds of Jatropha is $1,589 \mathrm{~kg} \mathrm{ha}^{-1}$ of oil per year, on average. ARRUDA et al. (2004) emphasize that the production of oil reaches $2,000 \mathrm{~kg} \mathrm{ha}^{-1}$ at culture productive age, which is about 3 to 4 years of age. LAPOLA et al. (2009) report that, in pressing process, a ton of Jatropha seeds has an average yield of 277.5 liters of biodiesel, assuming seed oil content of $34 \%$ and $75 \%$ of extraction efficiency.

In terms of oil content, MARTINS \& CRUZ (1985) reported that the average content of oil from Jatropha seeds is around 35\%. TEIXEIRA (1987) found that the oil content of Jatropha seeds evaluated ranged from 23 to $34 \%$, justifying that this variation was due to the locality, cultural practices and genetic variability of the species.

Some researchers point out that the Brazilian Jatropha is a species with great potential, but there are many uncertainties regarding the agronomic aspects, such as the behavior of the growth, production, fluid and nutritional requirements, among many others, requiring studies supporting these key variables which guide decisions in production systems (SATO et al., 2007; SILVA et al., 2009; CHAVES et al., 2010).

In relation to water requirements, it is known that water is a determining factor in plant growth, limiting agricultural productivity of crops, because it contributes in various metabolic processes which converge in plant development (PIMENTEL, 2004). Specifically with regard to the behavior of Jatropha in the use of irrigation, EVANGELISTA et al. (2011) report that the crop responds well to irrigation, directly affecting their productivity. Additionally, irrigation interferes directly in growth parameters of culture, as emphasized in the conclusions of FARIA et al. (2011). In general, besides the appropriate fertilization, efficient water supply interferes directly in the development and production of agricultural crops. Given the above, the objective of this study was to evaluate the behavior of Jatropha seed oil content and yield depending on the differentiation of irrigation depths and potassium levels, in the city of Lavras, state of Minas Gerais (MG).

\section{MATERIAL AND METHODS}

The experiment conducted in the Fruitculture area of the Department of Agriculture, of the


originated the grains used in determining the oil content, and these determinations were conducted at the Laboratory of Water Analysis (LAADEG) and Laboratory of oils, fats and biodiesel of the Engineering Department, of the Federal University of Lavras. 
The city of Lavras has a Cwa climate, with mean annual air temperature of $19.4^{\circ} \mathrm{C}$, mean relative humidity of $76.2 \%$, mean annual rainfall of $1,529.7 \mathrm{~mm}$ and mean annual evaporation of 1,034.3 mm (DANTAS et al., 2007).

The seedlings of Jatropha (Jatropha curcas L.) were planted in the furrow, manually, with spacing of $3.0 \mathrm{~m}$ between planting rows and $1.5 \mathrm{~m}$ between plants.

Generated information originated from the application of four treatments related to irrigation depths, and four treatments related to the potassium dosages. The irrigation depths were applied in the effectively irrigated areas, based on the percentage of the balance of accumulated evaporation of Class A tank (ECA) and the rainfalls, being as follows: L0 $=$ without irrigation, $L 40=40 \%$ of the balance, $\mathrm{L} 80=80 \%$ of the balance, and L120 $=120 \%$ of the balance. The potassium dosages were applied to each production cycle of the crop, in the irrigation water, in the following dosages: $\mathrm{K} 30=$ $30 \mathrm{~kg} \mathrm{ha}^{-1}, \mathrm{~K} 60=60 \mathrm{~kg} \mathrm{ha}^{-1}, \mathrm{~K} 90=90 \mathrm{~kg} \mathrm{ha}^{-1}$, and $\mathrm{K} 120=120 \mathrm{~kg} \mathrm{ha}^{-1}$, where the potassium source was potassium chloride $\left(58 \% \mathrm{~K}_{2} \mathrm{O}\right)$. The experiment was conducted based on experimental design with randomized blocks, in split-plots with four replications, where the irrigation depths were randomly assigned in blocks, and potassium dosages within each treatment of irrigation depth. Each plot consisted of six rows of Jatropha, spaced by $3 \mathrm{~m}$, with a length of $12 \mathrm{~m}$, consisting of 48 plants, with a total area of $216 \mathrm{~m}^{2}$. The floor area of the experimental plot was $108 \mathrm{~m}^{2}$, where the 4 central lines were considered, with 16 plants considered useful. The sub-plot was represented by each central line, with 4 plants of Jatropha per planting row.

The climatological parameters of evaporation and precipitation were obtained from the Main Climatological Station of Lavras - INMET ( $5^{\text {th }}$ District of meteorology - city of Belo Horizonte, MG), located 300 meters from the experimental area. Irrigation was performed twice a week (Tuesdays and Fridays), and drippers were used with flow rate of $1.6 \mathrm{~L} \mathrm{~h}^{-1}$, spaced by $0.50 \mathrm{~m}$, forming a continuous wet area along the planting rows. The irrigation time was determined by following methodology of BERNARDO et al. (2006), according to equation 1.

$$
T i=\frac{\left\lfloor\left(\sum E C A-\Sigma P\right) / E\right\rfloor \cdot A}{n g \cdot q}
$$

In which,

$\mathrm{Ti}$ - irrigation time, h;

$\sum E C A$ - sum of evaporation of Class A Tank occurred in the interval between irrigation, mm; $\sum \mathrm{P}$ - sum of rainfall occurred in the interval between irrigation, $\mathrm{mm}$;

E - irrigation system efficiency (0.95), decimal;

A - wet area provided by lateral row $\left(0.25 \mathrm{~m}^{2}\right), \mathrm{m}^{2}$;

ng - number of drippers per lateral row, and

$\mathrm{q}$ - dripper flow, $\mathrm{L} \mathrm{h}^{-1}$.

It was analyzed the data of oil content and yield, and the efficiency of water use in the production of Jatropha oil, and for determining the oil content, it was used grains from sampling of two grain yields of Jatropha of 2009, which refers to the second year of production, and third year of culture.

The oil extraction was performed chemically using organic solvent (Hexane) in an extraction apparatus of Soxhlet type, following guidelines of MENDONÇA FILHO et al. (2010), and, for this, the samples were previously crushed and placed in envelopes of filter paper in the average amount of $2.5 \mathrm{~g}$, in which were produced 3 sub-samples (repetitions) for each treatment $(3 \times 64$ treatments $=$ 192 sub-samples). The extraction time for each sample was 2 hours and 30 minutes, which were subsequently dried at $60^{\circ} \mathrm{C}$ for 30 minutes, so that the humidity would not alter the mass of the dry sample. The mass of each repetition was measured with a precision scale after kiln drying. The oil content of each treatment was determined using the equation 2. 


$$
T O=\left[\frac{\left(P_{\text {paper }}+P_{\text {sampling }}\right)-P_{\text {final }}}{P_{\text {sampling }}}\right] .100
$$

In which,

$\mathrm{TO}$ - content of grain oil, \%;

$\mathrm{P}_{\text {paper }}$ - weight of filter paper, $\mathrm{g}$;

$\mathrm{P}_{\text {sampling }}$ - weight of crushed sampling, $\mathrm{g}$, and

$\mathrm{P}_{\text {final }}-$ weight of sampling and filter paper after the test, $\mathrm{g}$.

The oil yield of each treatment was estimated by equation 3, based on information of DEUS (2010) in the grain yield of Jatropha of the second year of production.

$$
P_{\text {oil }}=\frac{T O}{100} \cdot P_{2009}
$$

In which,

$\mathrm{P}_{\mathrm{oil}}$ - estimated yield of oil, $\mathrm{kg} \mathrm{ha}^{-1}$;

TO - content of grain oil, $\%$, and

$\mathrm{P}_{2009}$ - yield of Jatropha grain for the second year of production, $\mathrm{kg} \mathrm{ha}^{-1}$.

The collected data were statistically analyzed using analysis of variance, and for those factors that showed significant differences by the $\mathrm{F}$ test, equation adjustments were made using regression analysis. It was analyzed the levels of irrigation, potassium doses, as well as the interaction between them, as quantitative factors, with the aid of the Sisvar computer program.

\section{RESULTS AND DISCUSSION}

Table 1 presents a summary of the analysis of variance, at $5 \%$ probability, for data of oil content and yield of Jatropha grain samples for the second year of crop production, and for efficiency data for the total water applied to the crop of Jatropha converted to total oil yield.

TABLE 1. Variance analysis for oil content and yield, and water use efficiency for oil production.

\begin{tabular}{ccccc}
\hline \multirow{2}{*}{ Variation source } & GL & \multicolumn{4}{c}{ Mean Square } \\
\cline { 3 - 5 } & & Oil content $(\%)$ & Oil yield $\left(\mathrm{kg} \mathrm{ha}^{-1}\right)$ & Water use efficiency $\left(\mathrm{kg} \mathrm{ha}^{-1} \mathrm{~mm}^{-1}\right)$ \\
\hline Depths & 3 & $8.47^{*}$ & $53,349.61^{*}$ & $0.0141^{*}$ \\
Residue 1 & 9 & 0.57 & $6,351.74$ & 0.001032 \\
Potassium & 3 & $0.33^{\mathrm{ns}}$ & $27,975.32^{\mathrm{ns}}$ & $0.00579^{\mathrm{ns}}$ \\
Depth x Potassium & 9 & $1.54^{\mathrm{ns}}$ & $5,639.21^{\mathrm{ns}}$ & $0.000984^{\mathrm{ns}}$ \\
Residue 2 & 36 & 1.11 & $9,783.05$ & 0.001924 \\
Total & 60 & - & - & - \\
Overall Mean & - & 33.25 & 352.54 & 0.16 \\
CV1(\%) & - & 2.28 & 22.61 & 19.82 \\
CV2(\%) & - & 3.17 & 28.06 & 27.06 \\
\hline
\end{tabular}

ns - not significant, $*$ - significant at $5 \%$ probability

It can be observed that the only differentiation of the water depth influenced statistically the oil content and yield, as well as the water use efficiency in oil production (Table 1), and in Table 2 it can be observed the results of regression analysis for parameters that were significant by the $\mathrm{F}$ test. 
TABLE 2. Regression analysis for oil content and yield, and water use efficiency for oil production, depending on the differentiation of irrigation depths.

\begin{tabular}{ccccc}
\hline \multirow{2}{*}{ Model } & GL & $\begin{array}{c}\text { Oil content } \\
(\%)\end{array}$ & $\begin{array}{c}\text { Oil yield } \\
\left(\mathrm{kg} \mathrm{ha}^{-1}\right)\end{array}$ & $\begin{array}{c}\text { Water use efficiency } \\
\left(\mathrm{kg} \mathrm{ha}^{-1} \mathrm{~mm}^{-1}\right)\end{array}$ \\
\hline Linear & 1 & $18.99^{*}$ & $49,043.62^{*}$ & $0.0201^{*}$ \\
$2^{\text {nd }}$ degree polynomial & 1 & $3.44^{*}$ & $78,500.83^{*}$ & $0.013^{*}$ \\
Square root & 1 & $2.99^{\mathrm{ns}}$ & $32,504.37^{\mathrm{ns}}$ & $0.009^{\mathrm{ns}}$ \\
Residue & 57 & 0.57 & $6,351.74$ & 0.001 \\
Total & 60 & - & - & -
\end{tabular}

Except for the square root model, all models evaluated (linear and $2^{\text {nd }}$ degree polynomial) adapted with the statistical data, which the model that showed higher coefficient of determination (R2) was chosen for each parameter, and for all situations related to the $2^{\text {nd }}$ degree polynomial model.

In assessing the oil content according to irrigation depths, it was noted relative decrease of values with the increase of the depths (Figure 1). The maximum value (33.81\%) of oil content was achieved using a water depth of $250 \mathrm{~mm}$ for 2009 , on the irrigation treatment of $25.09 \%$ of the balance.

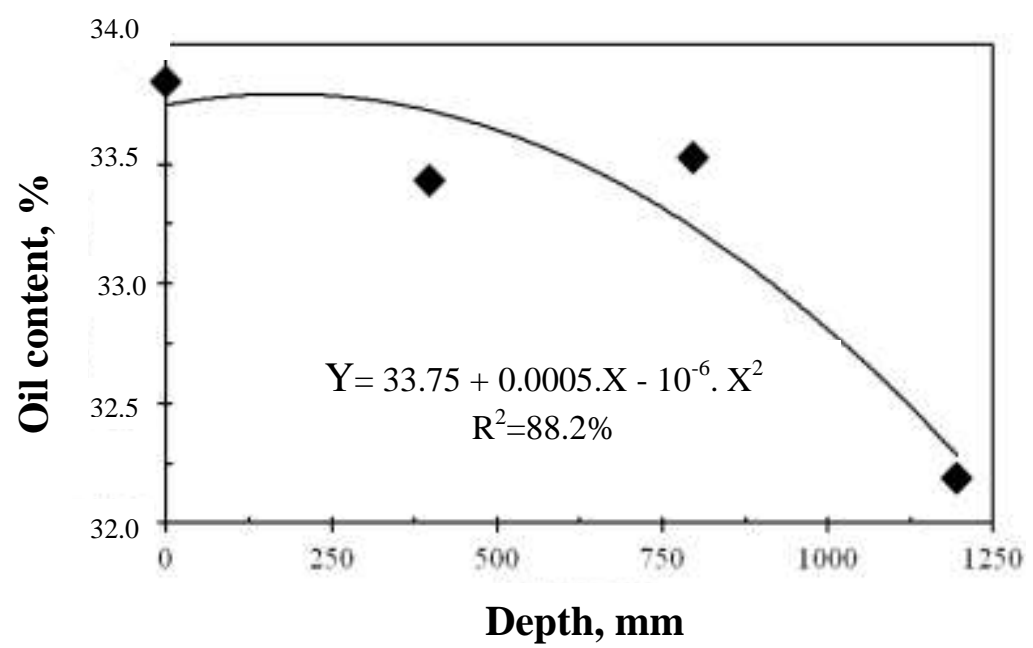

FIGURE 1. Graphing and regression equation of Jatropha oil content as a function of irrigation depth applied.

The oil content values obtained for this study (32.3 to $33.8 \%$ ) are inserted at intervals of values highlighted by TEIXEIRA (1987) (23 to 34\%) and NUNES et al. (2008) (32 to 38\%), however, in studies done by SOUSA et al. (2011), evaluating the influence of irrigation depths with wastewater in the oil content of Jatropha seeds, longer intervals were observed in oil content compared to the results of the present study, ranging from 20 to $35 \%$ of oil content. Another difference found in relation to the SOUSA et al. (2011) study relates to the behavior of the values of oil content with the depth increasing, where, unlike the results of this study, an increase of values was observed. The differences observed may be related to the methodology used to estimate the oil content, because in the SOUSA et al. (2011) study, it was used nondestructive analysis by nuclear magnetic resonance to low field. Additionally, it is known that the geographic location is a factor that affects the values of oil content in Jatropha grains (TEIXEIRA, 1987), and it is possible, in this case, to have influenced the magnitude of the values found. 
Regarding oil yield, it is observed in Figure 2 that there is a tendency of relative increase in function of irrigation depth applied, reaching an approximately constant level.

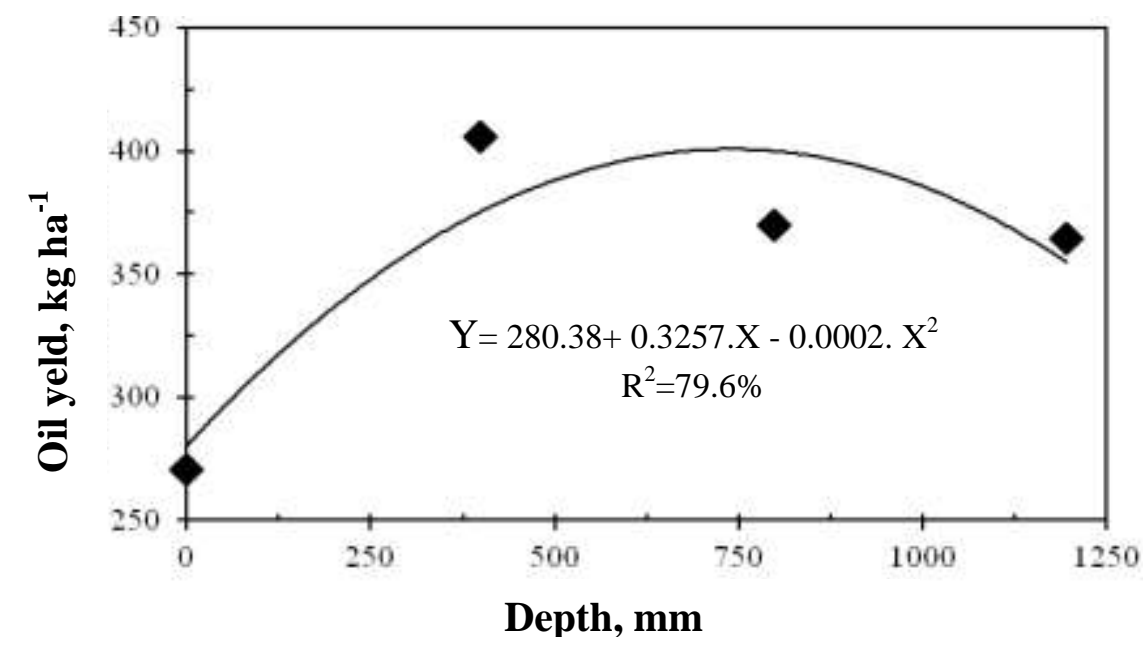

FIGURE 2. Graphing and regression equation of the Jatropha oil yield as a function of irrigation depth applied.

The point of maximum technical efficiency of oil yield $\left(412.98 \mathrm{~kg} \mathrm{ha}^{-1}\right)$ was achieved using an irrigation depth of $814.25 \mathrm{~mm}$, which refers to a factor of water replenishment of $81.71 \%$. There was an increase of $47.29 \%$ in oil yield, comparing the point of maximum technical efficiency to the estimated yield for the situation without irrigation $\left(280.38 \mathrm{~kg} \mathrm{ha}^{-1}\right)$. Additionally, in comparison with information found in the literature (average oil yield from 1,600 to 2,000 kg ha ${ }^{-1}$ ) (TEIXEIRA, 2005; EPAMIG, 2006; ARRUDA et al., 2004), it is observed that the production of oil, even for the irrigated treatment, showed 4 to 5 times inferior.

In summary, the adoption of irrigation caused a reduction of oil content in seeds of Jatropha; however it determined increase in oil yield of the crop. According to MARCOS FILHO (2005), the effects of the environment, including water availability, may change the chemical composition of the seeds during development, i.e., the proportion of its components. In this case, the grains of Jatropha with higher weight, status affected with the increase of water levels applied in the study developed by DEUS (2010), may have increased the percentage of components related to protein and starch in relation to lipid, indeed resulting in decreasing the ratio of lipid weight and total weight of the grains, or decreasing oil content. Relative to water use efficiency in the Jatropha oil yield, it is observed in Figure 3 a relative increase to a certain water depth value (irrigation + rain), from which a decrease was observed.

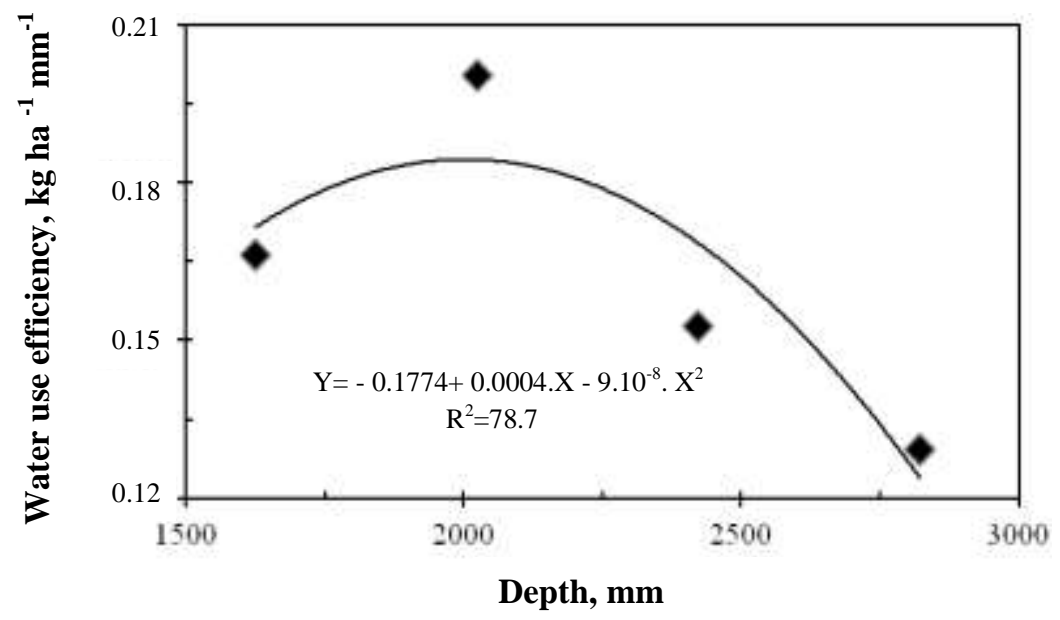

FIGURE 3. Graphing and regression equation of the water use efficiency for Jatropha oil yield as a function of irrigation depths applied. 
The point of maximum efficiency in water use in the Jatropha oil yield $\left(0.1843 \mathrm{~kg} \mathrm{ha}^{-1} \mathrm{~mm}^{-1}\right)$ was reached for a water depth (rain + irrigation) of $2,002.53 \mathrm{~mm}$, which refers to a treatment of water depth of $39.57 \%$. Considering the treatment of irrigation for the point of maximum technical efficiency of oil yield $(81.71 \%-2,474.83 \mathrm{~mm})$, it was estimate a water use efficiency in the order of $0.1669 \mathrm{~kg} \mathrm{ha}^{-1} \mathrm{~mm}^{-1}, 10.43 \%$ lower than in the treatment of irrigation depth of $39.57 \%$.

\section{CONCLUSIONS}

The use of irrigation in the cultivation of Jatropha provided a decrease in the values of grain oil content; however it caused an increase of oil yield, which was provided by the increase in grain yield with the increasing of irrigation depths.

Potassium fertilization did not affect the culture in terms of oil content and yield.

There was an increase of water use efficiency in oil yield by a certain water depth with subsequent decrease.

\section{REFERENCES}

ARRUDA, F.P.; BELTRÃO, N.E.M.; ANDRADE, A.P.; PEREIRA, W.E.; SEVERINO, L.S. Cultivo de pinhão manso (Jatropha curcas L.) como alternativa para o semi-árido nordestino. Revista Brasileira de Oleaginosas e Fibrosas, Campina Grande, v. 8, n.1, p. 789-799, 2004.

BERNARDO, S.; SOARES A.A.; MANTOVANI, E.C. Manual de irrigação. 8. ed. Atualizada e ampliada. Viçosa: UFV, 2006. 625 p.

CHAVES, L.H.G.; MESQUITA, E.F.; ARAUJO, D.L.; FRANÇA, C.P. Crescimento, distribuição e acúmulo de cobre e zinco em plantas de pinhão-manso. Revista Ciência Agronômica, Fortaleza, v. 41, n. 02, p. 167-176, 2010.

DANTAS, A.A.A.; CARVALHO, L.G.; FERREIRA, E. Classificação e tendências climáticas em Lavras, MG. Ciência e Agrotecnologia, Lavras, v. 31, n. 6, p. 1862-1866, nov./dez. 2007.

DEUS, F.P. Produção de pinhão manso submetido a diferentes lâminas de irrigação e níveis de adubação potássica. 2010. 81 f. Dissertação (Mestrado em Irrigação e Drenagem) - Universidade Federal de Lavras, Lavras, 2010.

EPAMIG. Empresa de Pesquisa Agropecuária de Minas Gerais. Coletânea sobre pinhão-manso na EPAMIG. Belo Horizonte, 2006. Disponível em: <www.epamig.br/informativos/pinhaomanso.pdf>. Acesso em: 17 jul. 2010.

EVANGELISTA, A.W.P.; MELO, P.C.; OLIVEIRA, E.L.; FARIA, M.A. Produtividade e rendimento de sementes de pinhão-manso submetido à irrigação e adubação com OMM-TECH. Revista Engenharia Agrícola, Jaboticabal, v. 31, n. 2, p. 315-323, 2011.

FARIA, M.A.; EVANGELISTA, A.W.P.; MELO, P.C.; ALVES JÚNIOR, J. Resposta da cultura do pinhão manso à irrigação e à adubação com OMM-TECH. Irriga, Botucatu, v. 16, n. 1, p. 70-81, 2011.

LAPOLA, D.M.; PRIESS, J.A.; BONDEAU, A. Modeling the land requirements and potential productivity of sugarcane and jatropha in Brazil and India using the LPJmL dynamic global vegetation model. Biomass \& Bioenergy, Silver Spring, v. 33, n. 8, p. 1087-1095, Aug. 2009.

LAVIOLA, B.G.; DIAS, L.A.S. Teor e acúmulo de nutrientes em folhas e frutos de pinhão manso. Revista Brasileira de Ciência do Solo, Viçosa, MG, v. 32, n. 5, p. 1969-1975, 2008.

MARCOS FILHO, J. Fisiologia de sementes de plantas cultivadas. Piracicaba: Fealq, 2005. 495 p.

MARTINS, E.R.F.; CRUZ, N.D. Pesquisas em desenvolvimento com pinhão-paraguaio no Instituto Agronômico. O Agronômico, Campinas, v. 37, n. 2, p. 109-113, 1985. 
MELHORANÇA FILHO, A.L.; PEREIRA, M.R.R.; SILVA, J.I.C. Potencialidade energética em extratores e tempos de extração do óleo de Pinhão-manso (Jatropha curcas L.) em soxletter. Bioscience Journal, Uberlândia, v. 26, n. 2, p. 226-230, mar./abr. 2010.

NUNES, C.F.; PASQUAL, M.; SANTOS, D.N. dos; CUSTÓDIO, T.N.; ARAÚJO, A.G. de. Diferentes suplementos no cultivo in vitrode embriões de pinhão manso. Pesquisa Agropecuária Brasileira, Brasília, v.43, p.9-14, 2008.

OLIVEIRA, J.S.; LEITE, P.M.; SOUZA, L.B.; MELLO, V.M.; SILVA, E.C.; RUBIM, J.C.; MENEGHETTI, S.M.P.; SUAREZ, P.A.Z.

CharacteristicsandcompositionofJatrophagossypiifoliaandJatrophacurcas L. oils and application for biodiesel production. Biomass \& Bioenergy, Silver Spring, v. 33, n. 3, p. 449-453, Mar. 2009.

PIMENTEL, C. A relação da planta com a água. Seropédica: EDUR, 2004. 191p.

SATO, M.; BUENO, O.C.; ESPERANCINI, M.S.; FRIGO, E.P. A cultura do Pinhão-manso (Jatrophacurcas L.): Uso para fins combustíveis e descrição agronômica. Revista Varia Scientia, Cascavel, v. 7, n. 13, p. 47-62, 2007.

SILVA, E.N.; SILVEIRA, J.A.G.S.; FERNANDES, A.T.B.D.; ARAGÃO, R.M.Acúmulo de íons e crescimento de pinhão-manso sob diferentes níveis de salinidade. Revista Ciência Agronômica, Fortaleza, v. 40, n. 02, p. 240-246, 2009.

SOUSA, A.E.C.; GHEYI, H.R.; SOARES, F.A.L.; MEDEIROS, E.P.; NASCIMENTO, E.C.S. Teor de óleo no pinhão manso em função de lâminas de água residuária. Pesquisa Agropecuária Brasileira, Brasília, v.46, n.1, p.108-111, 2011.

TEIXEIRA, J.P.F. Teor e composição do óleo de sementes de Jatrophaspp. Bragantia, Campinas, v. 46, n. 1, p. 151-157, 1987.

TEIXEIRA, L.C. Potencialidades de oleaginosas para produção de biodiesel. Informe Agropecuário, Belo Horizonte, v. 26, n. 229, p. 18-27, 2005.

TRZECIAK, M.B.; NEVES, M.B.; VINHOLES, P.S.; VILLELA, F.A. Utilização de sementes de espécies oleaginosas para produção de biodiesel. Informativo Abrates, Londrina, v. 18, n. 1/3, p. 30$38,2008$. 